\title{
RESENHAS / REVIEWS
}

\section{Direito Aplicado ao Agronegócio: uma Abordagem MULTIDISCIPLINAR}

LAW APPLIED TO AGRIBUSINESS: A MULTIDISCIPLINARY APPROACH

PARRA, Rafaela Aiex (Org.). Direito Aplicado ao Agronegócio: uma abordagem multidisciplinar. $1^{\mathrm{a}}$ ed. Londrina: Thoth, 2018

\section{Rafaela Aiex Parra ${ }^{1}$}

A obra referenciada, organizada pela advogada e Mestranda pelo Programa em Direito Negocial da Universidade Estadual de Londrina - UEL, Rafaela Aiex Parra e que conta com o prefácio do advogado e Dr. pela Pontifícia Universidade Católica de São Paulo, Renato Buranello, é resultado da compilação de artigos na seara do agronegócio, e traz a análise de questões atuais e relevantes de interesse do setor, relacionados ao estudo das ciências econômicas, agrárias e jurídicas, principalmente nos ramos do Direito Civil, Direito Agrário e Direito Ambiental. Na introdução, há descrição sintética do conceito do agronegócio brasileiro, com as definições de nomenclaturas inseridas no Complexo Agroindustrial e no Sistema Agroindustrial. O primeiro capítulo, assinado pelo Professor titular da Universidade de São Paulo - USP de Ribeirão Preto, Dr Rogério Alessandre de Oliveira Castro, traz discussão sobre a inserção do Direito do Agronegócio como sub-ramo do Direito Comercial, fazendo análise

1 Mestranda em Direito Negocial pela Universidade Estadual de Londrina (UEL). Advogada rp@advocaciarp.adv.br 
do PLS 487/2013, com seus principais pontos favoráveis. Na sequência, os professores Me. Albenir Querubini e Dr. Darcy Walmor Zibetti, Vice Presidente e Presidente da União Brasileira dos Agraristas Universitários, respectivamente, integram os conceitos de Direito Agrário e a sua relação com o agronegócio brasileiro, traçando um histórico deste ramo agrário no Brasil e enaltecendo os comandos do Estatuto da Terra e sua aplicabilidade. No que tange à correlação entre Direito Ambiental e agronegócio, são apontadas as principais legislações em sede ambiental pela professora Me. Luisa Falkenberg e os reflexos para a gestão e gerenciamento dos empreendimentos do setor agrícola. A visão do agronegócio e da agricultura no século XXI, sob o aspecto econômico precipuamente, é delineada pelo economista Dr. Antônio da Luz, seguida de análise sobre a agricultura familiar e patronal pelo Doutorando em Economia pela ESALQ - USP, Rodrigo Peixoto da Silva. Os padrões de consumo, bem como a supremacia do poder econômico como regulador do mercado capitalista e os limites esperados pela regulação do Direito são os temas tratados pelos Mestrandos pelo Programa em Direito Negocial da Universidade Estadual de Londrina - UEL, Rafaela Aiex Parra, Túlio Santos Caldeira e Uiara Vendrame Pereira. Prosseguindo, são apresentados pela organizadora da obra, ora autora, Rafaela A. Parra, os desafios do agronegócio brasileiro, em razão do aumento populacional mundial estimado para o ano de $2050 \mathrm{em}$ mais de $70 \%$, que forçará a produção agrícola global a ser majorada em $40 \%$. Ainda neste texto são apresentados dados sobre o destaque da legislação florestal brasileira quando comparada à legislação de países como China, França, Alemanha, Argentina, Canadá e Estados Unidos. "[...] a necessidade de educação ambiental e a sincronia de todos os tópicos da sustentabilidade (política, 
ética, jurídica, ambiental, social, econômica), tanto na produção, quanto na cadeia consumidora é de extrema necessidade para que os efeitos da globalização una os povos em um mesmo objetivo." (PARRA, 2018, p. 202). No tocante à propriedade rural, as pesquisadoras vinculadas ao programa Input.org, Me. Cristina Leme Lopes e Dra. Joana Chiavari, discutem a governança fundiária no Brasil, os diferentes cadastros rurais adstritos à propriedades, com foco nas particularidades do Cadastro Ambiental Rural. No curso da obra, tema de Direito Civil é posto à tona pelo Me. Albenir Querubini, ao tratar da possibilidade do contrato de franquia empresarial por produtores rurais, evidenciando as mudanças a partir do Código Civil de 2002. O advogado e Me. Sergio Eduardo Canella, ainda sob o âmbito do Direito Civil, aborda a Teoria da Empresa e os conceitos de empresa rural, evidenciando conceitos jurídicos e econômicos para efetiva aplicabilidade no agronegócio. A perspectiva dos contratos agrários agroindustriais e o cotejo com a lei 13.288/2016 é tema desenvolvido pelo advogado e Me. Francisco de Godoy Bueno. Alusão aos Contratos de Arrendamento Rural, seus prazos e fixação de preços, é conteúdo do estudo elaborado pela já referenciada organizadora da obra, Rafaela A. Parra, e o advogado Francisco Luís Hipólito Galli. Mote relevante e atual é dissertado pelo advogado gaúcho, Francisco Torma, que traz ao leitor histórico, legislação e especificidades acerca do endividamento rural e as consequências das renegociações de dívidas do crédito rural ao produtor, apontando as hipóteses de restrição do crédito e as garantias para negócios futuros. Sucedendo este assunto tão relevante, surge o conteúdo escrito pelo advogado e Mestrando em Desenvolvimento Local em Contexto de Territorialidades pela Universidade Católica Dom Bosco - UCDB, Pedro Puttini Mendes, que pauta histórico normativo sobre o FUNRURAL, os julgamentos 
proferidos no Supremo Tribunal Federal, discussões sobre constitucionalidade e inconstitucionalidade da legislação, além de estudo sobre a legislação infraconstitucional e medidas legislativas e executivas. Este estudo é seguido do artigo de produção do Procurador do Distrito Federal e Me. em Direito Agrário, Rogério Oliveira Anderson, sobre as consequências práticas ao produtor rural em razão do julgamento que envolve a cobrança do FUNRURAL. Também assunto que merece destaque é o artigo de autoria da Mestranda pelo Programa em Direito Negocial da Universidade Estadual de Londrina - UEL, Jussara Romero Sanches, que discorre sobre o Licenciamento Ambiental, seu projeto de alteração em trâmite (PL 3.729/2004) e os principais pontos que o revestem como instrumento de proteção ambiental e garantia da ordem econômica. Noções sobre o Cadastro Ambiental Rural são reproduzidas pela advogada e Zootecnista, Me. Aniele Pissinati, continuada por detalhado trabalho do advogado Antônio Fernando Pinheiro Pedro sobre o Código Florestal Brasileiro, que narrou as origens da agricultura, com forte viés histórico, desde a época das sesmarias, passando pelo surgimento da codificação florestal até os últimos processos legislativos e judiciais para a aplicação da norma florestal. O julgamento sobre a constitucionalidade da Lei $\mathrm{n}^{\mathrm{o}}$ 12.651/2012, Código Florestal Brasileiro, deu espaço para a elaboração de estudo sobre a economia de baixo carbono no Brasil, capitaneada pela advogada e organizadora desta obra, Rafaela A. Parra, com a participação em co-autoria dos advogados Murilo Meneguello Nicolau e Fabiana Moreira Zorzato, onde foi destaque o julgamento das ADIS n ${ }^{\circ} 4901,4902,4903$ e 4937 e da ADC nº 42, todas pelo STF. Apresentou-se o resultado do julgamento e seus efeitos práticos e dada ênfase ao art. 68 do Código Florestal, apontando para a necessidade de incremento de políticas que assegurem a utilização do mecanismo de 
compra e venda de créditos de carbono. Ainda na esfera ambiental, o advogado e Me. Alexandre Burmann, conduziu estudo sobre a conversão de multas em serviços ambientais, a partir do exame ao Decreto Federal $n^{\circ} 6.514 / 2008$ e o Decreto Federal no 9.179/17. Em sede econômicaadministrativa, Dr. Leonardo Papp fixou premissas para aplicabilidade dos conceitos de compliance ambiental, para mitigação de riscos jurídicos no agronegócio, apontando ferramentas à disposição para consecucão do objeto, bem como quais os riscos envolvidos, legislação aplicável e consequências jurídicas patrimoniais. No aspecto tributário, a contribuição ficou a cargo dos advogados Giuseppe Pecorari Melotti, Luiz Gustavo Antônio Silva Bichara e Thales Belchior Paixão, cujo trabalho versou sobre o mercado internacional que compõe o agronegócio nas exportações, esmiuçando o saldo credor acumulado de ICMS nestas operações e concluindo pela necessidade de edição de Lei Complementar para solução do assuntos em sede de reforma tributária, afim de conferir segurança jurídica à operações comerciais do agronegócio. Por derradeiro, fechando os trabalhos que compõem a presente obra, tem-se assunto de grande relevância na atualidade, subscrito pela advogada, Me. Caroline Zanetti Paiva, sobre a aplicação de métodos adequados de resolucão de conflitos ambientais e agrários, com destaque para a mediação, conciliação e arbitragem. 